\title{
6 Insurgent Ways of Looking: Gendering the Witness and the Land in the Visuality of Israel-Palestine
}

\section{Liat Berdugo}

In 2014, I was introduced to a special unit of exclusively female soldiers called Tatzpitaniot ("The Watchers") on a visit to an Israeli Defense Forces (IDF) army base in the occupied Palestinian Territories. As a woman and Israeli citizen myself, I have long been interested in the Israeli military and its gendered roles: under Israeli law I would have been conscripted into service, had my status as an American citizen and resident not exempt me. My visit thus evoked in me a vision of a life that might have been mine, but which I had, for better or worse, dodged.

It was vision, itself, that comprised the key task of these female soldiers whom I visited. Their sole job was to watch live video streams of the IDF's network of 1700 security cameras mounted along key sites in the West Bank and Gaza, in an effort to surveil Palestinians and secure Israel's borders (Harel, 2017). Often, these women watch multiple screens at once, staring at video feeds for hours at a time as they scan for movement. They report any "suspicious" visual activity to their army superiors, who then order on-the-ground action when deemed necessary (Gross, 2015). Put differently, the sole task of a Tazpitaniah, a "watcher," is to weaponize her sense of sight.

The assignment to the Tazpitaniot brigade is deeply unpopular among Israeli conscripts. When a conscript asked on an online messaging board, "Is Tazpitanit an intersting [sic] army role?" others replied with comments such as "If you hate yourself then go there by all means," and "It is [as] interesting as is watching paint dry in real time... Get something else... Anything!" ("Is Tazpitanit an Intersting [sic] Army Role?”) Young Israeli women share strategies for 'failing' the Tazpitaniot's correlated vision examinations, encouraging each other to pretend not to see the computerized blinking cursors that test the accuracy and alacrity of their peripheral vision (Yom Hame'ah, 2015). These potential Tazpitaniot feign a kind of momentary blindness - a failure of vision that, I argue, has become a norm for Jewish Israelis wishing to ignore the unsightly monstrosity that is the occupation (Berdugo, 2017).

To combat these negative stereotypes, the IDF recently produced a promotional video titled "With Her Eyes She Defends Israel's Borders" (2019), valorizing the work of a watcher, a Tazpitaniah. The video features a single young woman in army fatigues, appearing an ordinary Israeli teenage soldier in every respect. The video declares, "She may look like any other soldier, but she has a secret weapon" - the camera zooms in dramatically on her face before the narrator continues - "her eyes" (see Figure 6.1). In this way, the video propagandizes her sense of sight, fully laminating together vision with weaponry. If "winning is keeping the target in constant sight" as Paul Virilio writes, then a Tazpitaniah must keep her eyes wide open (Virilio, 2009, p. 
2). One former soldier described that "Tazpitaniot are forbidden from looking away from our screens, for even a second” (Silkoff, 2018).

Perhaps predictably, the video concludes with a close up of the soldier's eyes. The narrator says, "It's thanks to women like her, who keep their eyes open, that millions of Israelis can close their eyes safely every night." The Tazpitaniah then winks knowingly at the camera (see Figure 6.2). A wink is a momentary closure of the eye, a flirt - a colluding gesture that accentuates the weapon she has sharpened to protect her nation. Her wink, we are to understand, is not a blink; instead she keeps one eye open at all times, training her watchful gaze on her target.

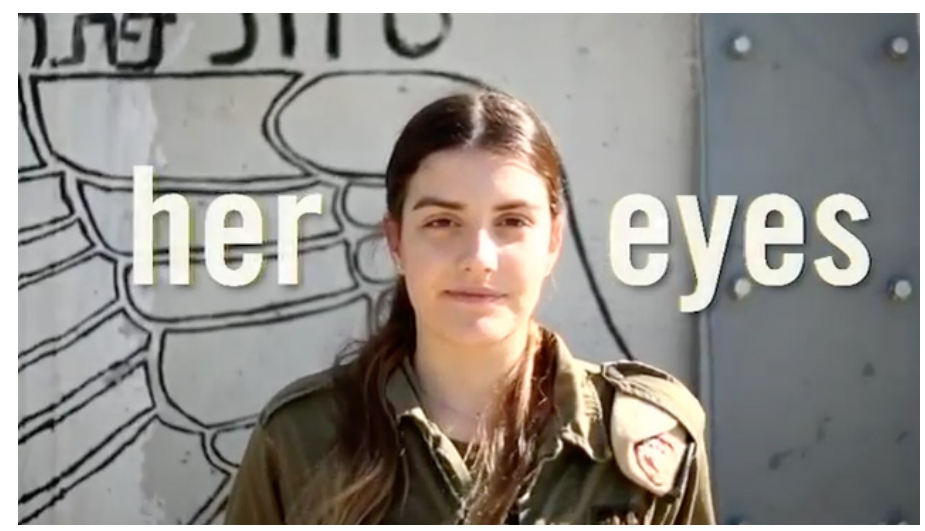

Figure 6.1: Video still from the Israeli Defense Forces' video, “With Her Eyes She Defends Israel's Borders," 2019.

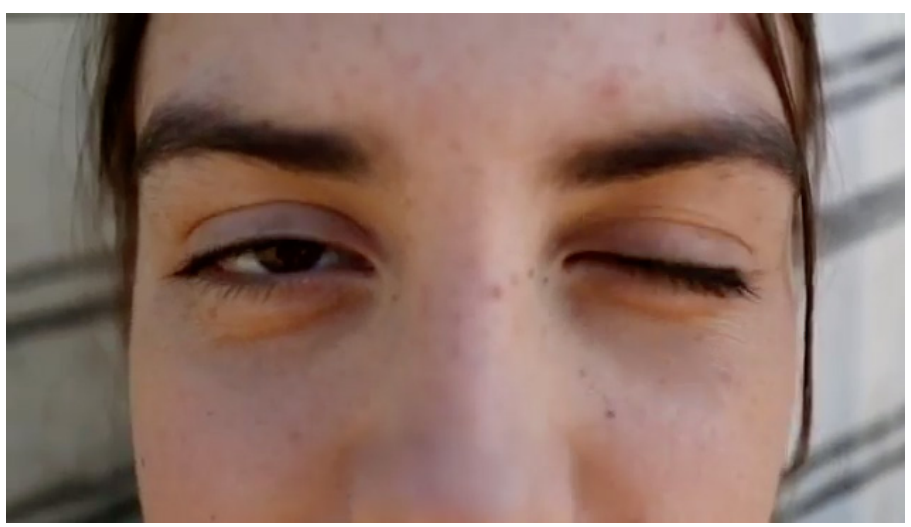

Figure 6.2: Video still from the Israeli Defense Forces' video, “With Her Eyes She Defends Israel's Borders," 2019. 
The women-only IDF unit relies on troubling stereotypes of the exclusively feminized eye as a maternal force of protection: a stereotype that extends responsibilities of an essentialized feminine, watchful gaze over children to a gaze that watches over territory. In Israel-Palestine, in a conflict that weaponizes and structures gazes (Azoulay, 2008, 2011a; Hochberg, 2015; Maimon \& Grinbaum, 2016; Berdugo, 2021), I argue that there has been a particular focus on the vision of and visual documentation produced by women as a problematically gendered force of protection. A woman's vision is celebrated as a militarized extension of the dominant Israeli scopic regime, as with the Tazpitaniot; as a Palestinian counter-visual tactic celebrated by the human rights group B’Tselem, which distributes cameras to Palestinians living in highconflict zones and gathers the footage. I show that in Israel-Palestine in particular, this focus on women's sight essentializes a long history of relating Zionism to the land, with all the feminized ideas associated with the land-based focus on "mother earth" or "mother nature" as a sustainer of people and the celebration of women's roles in Zionism as Haluzot (“female pioneers"). I critique such celebrations of women by turning towards ecofeminist critiques, which teach us to consider the ways in which women and the land have both been historically subjugated by a shared history of oppression. Ultimately, I argue in favor of de-gendering vision and de-gendering the land, instead towards a kind of sightline that celebrates a disobedient, insurgent way of looking: one that visibilizes the very frame of sight, and of the camera, as a means towards new kinds of resistance in conflict.

\subsection{A “One-Way Hierarchy of Vision"}

There is a striking similarity in looking down sightlines of a camera, and of a gun, in what many scholars have described as the joint and mutually entwined history of visuality and weaponry (Feldman, 1997; Sontag, 2002; Lebow, 2012). Virilio teaches that violence and visuality are concomitant, stating, "For men at war, the function of the weapon is the function of the eye" $(2009$, p. 26) This lethal mutuality has been cemented for video cameras in particular, as the first motion picture camera was invented to mimic the design of semi-automatic, revolving rifles (Lebow, 2012).

Drawing from this history, we can understand the role of "watchers" such as the IDF's Tazpitaniot not as an unexpected weaponization of sight, but a natural evolution of the militarization of the gaze. In Israel-Palestine, this is a militarization that extends to Israeli civilian bodies as well in an effort to surveil and control Palestinians. Architect Eyal Weizman has noted that Jewish settlements are often placed on hilltops or mountains, overlooking Palestinian villages that largely reside in the fertile valleys below, and thus creating a distinctly vertical separation between populations even as they are horizontally mixed (2007). In these settlements, the directions of roads, plots, the houses, and windows within the houses all direct an Israeli civilian gaze "out and down" over the Palestinian residents below, enlisting a civilian population 
to act as a watchful eye to monitor Palestinian action (Ibid., p. 132). Such settlements have transformed the West Bank into a network of visual monitoring stations, staffed by civilians who might also be "enjoying the view" (Ibid., p. 133).

However, Palestinians may not look at these Israeli Jewish settlements. According to the rules of engagement as of 2003, IDF soldiers may shoot-to-kill any Palestinian caught observing IDF activities near Israeli settlements with binoculars or in any other "suspicious manner" (Harel, 2003) Jewish Israelis thus maintain what Eyal Weizman has called a "one-way hierarchy of vision" over their Palestinian counterparts. Put differently, Israelis dominate what Nicholas Mirzoeff has called the "right to look" (2011), as a subset of a host of other visual rights: the right to see and to be seen; rights to look and to surveil; rights to be out of sight (of surveillance, for instance); and rights to have one's image trusted (rather than subject to a "digital suspicion" (Kuntsman \& Stein, 2015) through claims of photoshopping, cropping, or falsification in post-production). If "the gaze that sees is the gaze that dominates," as Foucault has written, then the seer has power over the seen (1994, p. 39). An uneven distribution of power in the realms of economics, politics, natural resources, equality, and justice within a conflict zone also reaches the realm of visuality itself.

It is against this backdrop that, in 2015 - the same year that YouTube was founded and video was gaining prominence on the Internet - an Israeli NGO called B'Tselem welcomed video into its repertoire by hiring a video coordinator and publicly including its videos as a main navigational component on its website (B'Tselem, 2005a). B'Tselem, also called The Israeli Information Center for Human Rights in the Occupied Territories, was established in 1989 by a prominent group of attorneys, academics, journalists, and Knesset members to document human rights violations in the Occupied Territories (B'Tselem, 2005b). Before adopting video as a tactic, B'Tselem published statistics, testimonies and eyewitness accounts, and reports in an effort to create a human rights culture in Israel.

At first, B'Tselem's videos were largely comprised of videotaped testimonies of Palestinian victims, which bolstered the organization's long-standing initiative to collect written testimonies from across the Occupied Territories (B'Tselem, 2005c). B'Tselem also produced short documentary videos that catalogued the hardships that the occupation placed Palestinians (B'Tselem, 2006). B'Tselem housed the role of its new video coordinator within its public relations department, signaling the organization's belief in the communicative potential of moving images.

In 2007, B'Tselem staff toured Hebron to see the conditions of Palestinians living adjacent to Israeli settlements (Tarabieh, 2019). Due to frequent settler attacks and stonings, Palestinian residents living in close proximity to the settlements were forced to erect metal grates around their houses for protection. As a result of its tour, B'Tselem resolved to give a video camera to one family who lived inside a "cage house", the Abu 'Ayeshas.

In January of 2007, a member of the Abu 'Ayesha family filmed the "Sharmuta" or "whore" video, a short clip in which an Israeli settler attempted to shut her into 
her house ("Sit here, in the cage!") and then bullies her by calling her a "whore" nine times in a hissing, menacing tone (B'Tselem, 2007). The Sharmuta video became the first ever citizen-recorded video in B'Tselem's camera distribution project and circulated widely within Israeli and international media outlets, to the point that it has become part of the Israeli lexicon (B'Tselem, 2009).

Thus the B'Tselem Camera Project was born, three years before the Arab Spring brought vast attention to the power of technology in the hands of the oppressed. Within its first year and a half, B'Tselem's distributed over one hundred cameras to Palestinian families in the Occupied Territories and hired two more staff members to support its growth (B’Tselem, 2008a and 2008b). Today there are around two hundred B'Tselem-issued cameras in the field, and B'Tselem has amassed an archive of over 4,500 hours of raw footage, which it keeps on a handful of different servers and in rows of original magnetic tapes behind glass doors in its Jerusalem headquarters (Tarabieh, 2019). B'Tselem's Camera Project is notable for the consistency of its video publication: the project has published an average of one video per week since its conception, often adding subtitles and other demarcations for the public. ${ }^{18}$ Today, B'Tselem's website prominantly features a carousel containing video footage shot by its volunteer videographers. On YouTube, B’Tselem's channel has over 43,000 subscribers, and its most popular video has been viewed over 4 million times (B’Tselem, 2017).

Notably, one thing that distinguishes the Israeli-Palestinian conflict is the freedom to record. Israeli law is more lenient on recording in public than is the US state of Massachusetts. In a letter from a Public Inquiries Officer, the IDF Central Command states, "filming in Judea and Samaria [the West Bank] is permitted, including filming of IDF soldiers, so long as nothing about the filming interferes with the forces' operations or serves to collect classified information" (2009). Moreover, the volunteers who film for B'Tselem sign an explicit legal document with the Israeli Defense Forces. Certain things are off limits to the camera's eye, such as court proceedings, army facilities, any persons working for Israel's internal security services ("Shabak" - similar to America's FBI), and checkpoints.

B'Tselem's Camera Project was launched with the conviction that a Palestinian with a camera reverses the normal order of domination under the Israeli occupation. Likewise, the citizen with the cell phone video of the police reverses the normal hierarchy of vision, which flows from state to people, from white to black. The reversal of the typical one-way hierarchy of vision allows for a view into the slow, suspended violence of the Israeli occupation (Azoulay \& Ophir, 2005). Yet, importantly, the majority of B’'Tselem videos are not leveraged as proof of Israeli criminality. Instead,

18 As of August 2019, B'Tselem had uploaded 631 videos to its YouTube channel, for an average of 1.01 videos per week in the twelve years since its founding. The remainder of the unpublished footage is viewable in B'Tselem headquarters with prior permission. 
they are mobilized as exculpatory evidence on behalf of Palestinians, themselves, who seek to prove their own assumed criminal bodies to be innocent (see also Finn, 2009). "When you are a Palestinian living in a place like Hebron, you are considered by the Israelis to be guilty unless proven innocent," said former B’Tselem volunteer, Issa Amro. He continued: “... for us, the cameras are not only a way to document events but also to protect ourselves when false complaints are made against us by Israeli soldiers.” Amro summed up what I heard from many B'Tselem volunteers in the field: the Palestinian video camera serves as a digital alibi. ${ }^{19}$

\subsection{A Woman's Camera}

B'Tselem volunteer videographers frequently referenced the exculpatory, defensive power of their cameras. Palestinian women, especially, speak of the camera as giving them strength, as if it were a shield or a piece of armor to deflect Israeli state violence. Among the B'Tselem volunteers, women have been growing in number in recent years, with $49 \%$ of the Camera Project's training sessions including women as of B'Tselem's most recent annual report (B'Tselem, 2018). B'Tselem makes an intentional effort to recruit women as volunteers by offering female-only training courses, and by appointing women as high-level paid employees for the Camera Project (Ginsburg, in press). Traditional Palestinian culture, which retains a rather conservative and patriarchal stance on women's roles (Baxter, 2007), was at first resistant to women's involvement as B'Tselem volunteer videographers. ${ }^{20}$ Yet recently, as these roles have been shifting, women with cameras have reported that their activities with cameras have become accepted and even praised within their communities (M. al-Ja'bri, 2019; A. al-Ja'bri, 2019; Jaber, 2019).

A B’Tselem volunteer named Khadrah 'Abd al-Karim from the Palestinian village of 'Asirah al-Qibliyah near Nablus, frequently videotapes the attacks from the nearby extremist Jewish settlement of Yitzhar. ${ }^{21} \mathrm{Al}$-Karim has been filming for B’Tselem since 2008, just one year after the Camera Project first launched. She said:

19 For more on the exculpatory role of the B'Tselem camera, see Berdugo 2021, and specifically the 2012 case of Palestinian teenager 'Abd al-'Aziz Fakhouri.

20 The women videographers who film for B'Tselem told me that these traditional gender roles vary from city to city and region to region. For instance, the videographers in Hebron feel these roles limit them more strongly than their counterparts in the Nablus area.

21 Yizhar is particularly known for its retaliatory Tag Mechir or Price Tag attacks, in which extremist Israeli settlers seek to harm and vandalize Palestinians and their property as a 'price' for Palestinian violence or for anti-settlement activity more generally. 
Filming the images is helpful to us. It has given me inner strength. I'm no longer scared. When they [Israeli settlers or soldiers] come, I go out. I used to hide when the soldiers came by. Now, I go outside with my husband. It has helped me very much on a personal level (B’'Tselem, 2014b).

Likewise, a volunteer named Lubna Saleh, began filming with a B'Tselem camera in 2007, after Israeli settlers set her family's car on fire. While she had previously felt a kind of fear of the settlers that kept her sealed within the domestic realm of her home, her camera has liberated her. She said:

I used to be scared to go out and face them [the settlers]. Now I'm not scared to go out and film.... True, I worry about getting injured, but I am more concerned about my children.... Sometimes, men ask me why I film. I tell them: to protect my home and my children (B’Tselem, 2014c).

To Saleh, the purpose of filming is to protect her domestic sphere (her home, her children). The camera has become a shield that safeguards the very realm over which she, as a woman, is traditionally held responsible. B'Tselem has made a point to call out women as the bearers of a particularly significant and unique burden of the Occupation's human rights violations:

Women are the ones who must find a way to run a household without regular or sufficient water. Women are the ones in charge of caring for children and they are the ones who must obtain food if their homes are demolished. Women are also usually the ones at home during settler attacks, so they are the ones who must shield their children (B'Tselem, 2014a).

In a traditional, patriarchal society, the realm of the woman is the home; yet the women from the village of "Asirah al-Qibliyah describe exiting the home in order to film with their B'Tselem cameras. They speak of "going out" or "going outside" the home as a marked difference from their previous actions of "hiding" inside their domestic spaces, feeling "scared.” Khadrah 'Abd al-Karim even intimated the outside realm as a distinctly masculine location when she said, "Now, I go outside with my husband." 'Outside' is the public sphere in which her husband appears, and in which she now joins because of her camera.

Many women volunteers who film for B'Tselem chose not to leave the home.Scholar Ruthie Ginsburg has researched the phenomenon of Palestinian women who film out their windows, making their own very private spheres sites for anti-colonial activism (Ginsburg, 2016). Of course, their homes are never quite private; the Palestinian home is constantly subject to the intrusion of the Israeli colonizing power, which 'makes its presence felt' through house searches, seizures, and demolition threats. But when women film out their windows, they achieve a superior perspective of 'looking down' at activity on the street, as if with the powerful view of Israeli hilltop settlements, just for a moment. Moreover women who film out their windows remain in their own distinct space, separate from the action 'out there'. Their acts of documentation therefore cannot be inhibited by physical assaults on the camera (such as grabbing, hitting, or breaking) because the camera resides in a separate space from the action. 
As Ginsburg has noted, a woman's “distinct space functions as a camera obscura - a darkroom where she sees and is unseen, watching the event without being a part of it” (Ibid., p. 49). In these cases, the Palestinian woman recording activates a mode of visual documentation in which, to put it crudely, her gender "protects" her footage.

The director of B'Tselem's video department, Ehab Tarabieh, reported that women currently comprise $40 \%$ of the Camera Project's volunteer videographers (2019). When asked of the growing number of women who volunteer, Tarabieh said, "Recently we want this," explaining that he believed these women to be "more calm" and not feeling the (implied masculine) urge to get involved in the altercations they record, therefore producing what he deemed "better" footage (Ibid.). Tarabieh said that most of B'Tselem's published footage has been recorded by women. B’Tselem celebrates women's participation in the Camera Project by featuring them in "campaigns, in articles and broadcasts that appear in the media, on the organization's blog, and in film festivals" (Ginsburg, in press, p.2) Tarabieh said to me, "Our dream [with the Camera Project] is to have only women," as they film much "better" than their male counterparts (2019).

Taken together, these personal comments and institutional celebration of the female videographer gesture towards something essential in women that produce the superior visual documentation of the Israeli occupation. While perhaps appearing feminist on the surface, this stance of celebration serves to gender the role of the witness - even as she wields the powerful video camera as a tool and weapon. While we might think B'Tselem's radical, counter-visual practices work "against the grain of normative representation," Ginsburg notes that the celebration and essentialization of women's visual documentation as providing a superior or unique perspective entails a problematic gendering that functions within - and problematically encourages normative representations of women in zones of conflict (in press, p. 18).

\subsection{Women's Ethical Agency in Conflict}

Conflict, it is often said, is a man's fault (as in, "Men start wars"). While sounding trite, scholars have long researched the ways in which women and men are treated differently in war. R. Charli Carpenter's research shows that women are more likely to be deemed civilians than men (2006). To the category of women, she adds other populations that are likely to be considered civilians, no matter their context: children, the elderly, the sick, and the disabled. Put differently, in conflict "femininity and masculinity are often coded: the former as civilians, the latter as combatants" (Ginsburg, in press, pp. 7-8).

Moreover, women in conflict are more likely to be portrayed as victims than their male counterparts. Wendy Hesford has noted that the Palestinian sufferer is visibilized as a feminized victim with whom a viewer should sympathize (2011). Hesford has noted that this feminization of the victim is problematic for its re-inscription of the 
spectator's Western and neoliberal values on the subject, thus confining her (often non-Western) body to a violently partialized set of comprehensions. Indeed, B'Tselem's portrayal of women as innocent parties who, as Ginsburg notes, "should be shielded from violence and saved" (Ginsburg, in press, pp. 10-11) further problematizes the gendered portrayal.

I'd like to focus on the notion of a shield, for a moment, as an object of protection which the feminized victim lacks, but deserves as a civilian wishing to remain safe in times of conflict. A shield is, by definition, an object of protection. The classic shield is a large piece of metal that one wears to protect against bodily harm (from a blow, or a projectile weapon). Shields therefore function in a necessarily preventative manner. Shields act as defenses, not offenses: they assume a kind of danger 'out there' from which the body requires protection. B'Tselem volunteer Shuruk Saleh describes how she "goes out" to the public realm of appearances to "defend [her] rights" with her camera. Indeed, the English word shield derives from the proto-Indo-European word, *(s)kelH-, meaning to "split" or "divide," as if to separate the interior vulnerability of the body from the violence of the exterior world. It is notably radical to portray the danger as 'out there', outside of Palestinian homes and instead in the space of appearances dominated and controlled by Jewish Israelis: such a portrayal reverses the occupation's narrative that it is Palestinians who are alien and violent intruders into Jewish Israeli space, and must, for instance, be kept in their place by an eight meter tall separation wall. Yet the very idea of a woman's need for a shield or defense plays into the idea that women are innocent civilians, victims, and generally lacking in political agency within the Israeli-Palestinian conflict.

\subsection{Watching the Land}

Allow me a brief detour to another zone of conflict: the contentious border between the United States and Mexico, where, in 2006, a program was founded to allow remote, civilian monitoring of the border in an American effort to curtail illegal immigration. A network of 200 security cameras were mounted along Texas's Rio Grande river, and were live-streamed online via a website called BlueServo.net (Moll, 2014). On BlueServo, citizens could flag and report suspicious activity, which was then sent to the corresponding Texas sheriff's office. The project transformed everyday civilians into a "Virtual Border Patrol" (or as the website called them, "virtual Texas deputies”) who aided US law enforcement agents (Burnett, 2009). While the program ended in 2012 due to lack of funding, its website is still active and accepting new user registrations, even though its "live" camera feeds are now reruns (Texas Border Watchers BlueServo). At its height, though, BlueServo boasted involvement by over 203,000 volunteer watchers, representing an estimated 1 million hours in free labor for the Texas Sheriff (Moll, 2014). 
Popular reporting on BlueServo focused on the role of women as watchers of the US border. Lori Andrews reported on an Oklahoma woman "who visits BlueServo each night after work and also tracks bald eagles online” and proclaimed, "II watch eagles and illegals. That's a fun thing to do"” (2012, p. 7). CNN focused its coverage on a "suburban stay-at-home mom" from Rochester, New York named Sarah Andrews, who spent at least four hours a day watching BlueServo (Suttler, 2009). According to CNN's reporting - which was quoted and circulated in major US news outlets such as The New York Times - Andrews used to watch the border "when her baby girl takes an afternoon nap," shifting her maternal, watchful gaze away from her daughter and directly towards the land, in what can only be described as a stunning feminized understanding of watching that echoes the Israeli Defense Force's Tazpitaniot brigade (Ibid.). ${ }^{22}$ Sarah Andrews and the all-female Tazpitaniot unit do not "guard" like soldiers, nor do they "defend" like Border Patrol agents; instead they "watch," like babysitters. $^{23}$

Palestinian women who film for B'Tselem also watch over the land with the eye of their lenses. In the more rural villages surrounding Nablus and South Hebron Hills, B'Tselem cameras are given to families living at the fringes of their villages who often are the first ones attacked by Israeli settlers nearby (a-Deb'I, 2019). Unlike B'Tselem volunteers who film in dense urban areas such as Hebron, these volunteers use tripods to stabilize their cameras as they record distant, sweeping, and often zoomed-in shots of their villages' land, its school, and agricultural or grazing fields that comprise their livelihood. Their use of tripods transforms their cameras into something more akin to mounted security cameras, aimed to watch the land and violations of it.

In unpublished footage from May of 2015, a B'Tselem volunteer named Thawra 'Eid filmed young Israeli settler children who had descended from a nearby Jewish settlement to launch an attack on her Palestinian village of Burin. Thawra films the wide expansive landscape between her home and the hill above as one of the settler children slingshots rocks in her direction (see Figure 6.3). As another example,

22 When asked why she watches the US-Mexican border, Andrews cited two reasons: first, she hoped her watchful eye would prevent drugs from reaching New York via Mexico; second, she describes herself as "nosy about what's going on" along the border.

23 A discussion of feminized watchers in Israel-Palestine would be incomplete without mention of Machsom Watch ("Checkpoint Watch"), a volunteer organization of Israeli women who have been observing the "West Bank checkpoints, the separation fences, the agricultural gates, the military courts and Palestinian villages” since 2001 as anti-occupation peace activists aiming to influence public opinion against the occupation and to curtail bad action by the Israeli soldiers they watch. The group is comprised of primarily female retirees, meaning a generation of women who could be the soldiers' mothers. They say, "When we look at the soldiers as our sons, part of our flesh and blood, the next generation - we fear the mental experience they have to go through and the ethical values they trample on during the military service in the Occupied Territories" (Machsom Watch, cited in Ginsburg, 2011). In this way, their watching ties explicitly to babysitting. For more on Machsom Watch, see Halperin (2007), Carter Hallward (2008), and Kutz-Flamenbaum (2012). 
a B'Tselem volunteer named Wydian Zaben filmed Israeli settlers as they torch the fields around Burin (see Figure 6.4). She documents the land to protect it, and to incriminate the settlers who aim to annihilate it. In both clips, we hear the women's children speaking in the background, reminding us that their gaze has not drifted far from their domestic life or indeed that they may be watching the land and their children, simultaneously.

I visited the homes of both Thawra and Wydian in 2019, accompanied by B'Tselem's field coordinator for the Nablus region named Salma a-Deb'i. Both women live at the outskirts of their Palestinian village that occupies a small fertile valley near Huwwara. As land became more expensive in the village, families like theirs began settling the hillsides of the valley, closer to the Jewish settlements and illegal Jewish outposts that sprung up on the hilltops above their village. Both Thawra and Wydian suffer from close proximity to the settler attacks, but also enjoy the scopic benefit of sweeping views of the village's land - views that are not beautiful nor enjoyable, but instead dangerous, heartbreaking, and rife with violence. Moreover, as mothers, both women frequently film attacks on Burin's single school which both their children attend, and which their homes look down upon with a clear unobstructed line of sight. Both women record Israeli settler attacks on the school from their homes.

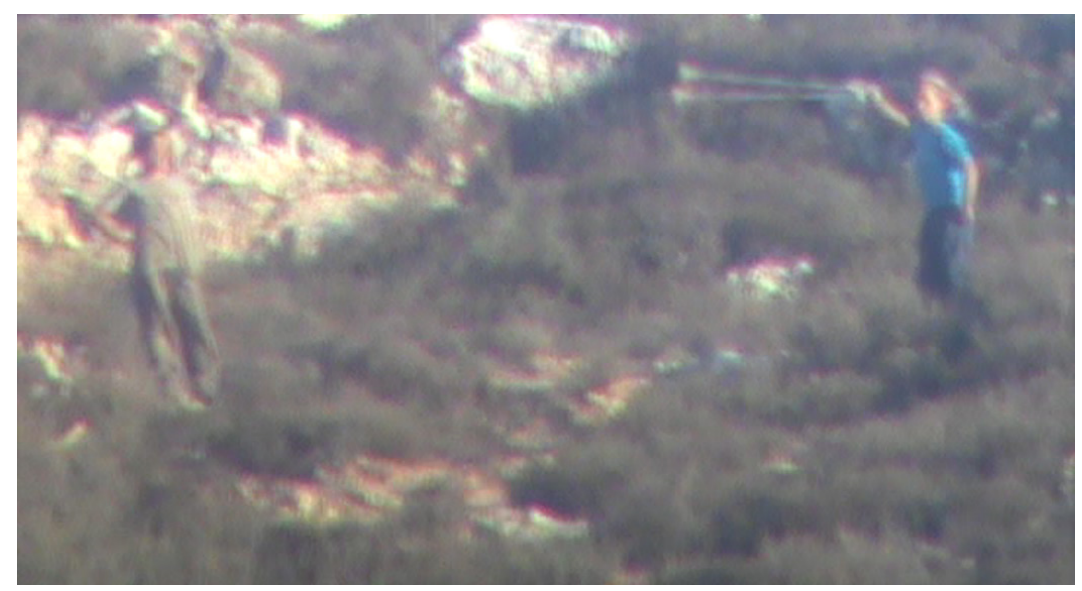

Figure 6.3: B'Tselem volunteer Thawra 'Eid zooms in on Israeli settler children who are attacking her Palestinian village of Burin by throwing stones with slingshots, May 20, 2015, ( ) B’Tselem. 


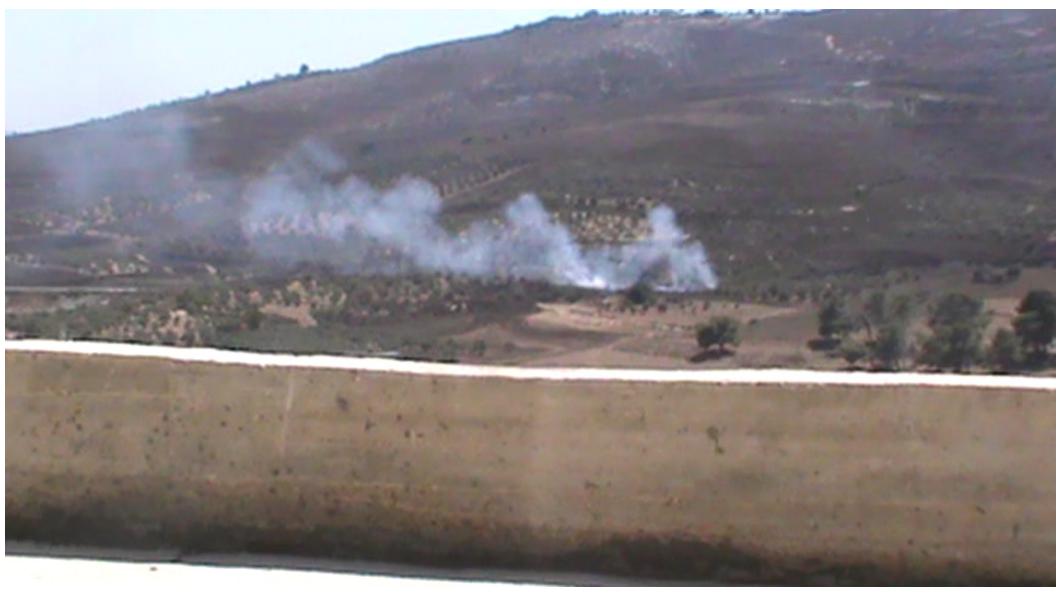

Figure 6.4: B'Tselem volunteer Wydian Zaben films Israeli settlers torching the fields around her Palestinian village of Burin, Aug 15, 2015, B’Tselem.

The settler violence in Burin is characteristic of a conflict entailing history of land disputes (Gerner, 1994; Caplan, 2011; Gelvin, 2014). Early Zionist efforts focused on land ownership and cultivation as a key feature of a new Jewish State. As Emanuela Rubenstein noted, "in the eyes of Herzl and his contemporaries, productivity meant one thing: engaging in agriculture” (Rubinstein, 2015). Agriculture was considered the key activity that transformed the character of the weak, urban Jew into a 'Sabra', a 'new Jew' who became strong, self-sufficient, and productive.

The shift towards agriculture entailed a shift in gender roles, as well. Eran Kaplan has written that mainstream Zionism entailed the "creation of a new society that would challenge traditional (diaspora) social divisions, including gender” instead fostering the images of "halutzim (male pioneers) and halutzot (female pioneers, see Figure 6.5) who together conquered the Palestinian wilderness" - a wilderness that was characterized as unproductive and barren by a Jewish colonial gaze (Kaplan, 2001, p. 12 ) The most radical experiment in gender equality was the Labor Zionist agricultural communes, or Kibbutzim, which boasted a view of women as equal to their male counterparts. Revisionist Zionists, on the other hand, continued to view the land as a distinctly "masculine sphere of play" whose boundary was extradomestic, while women remained relegated to the home and the family (Ibid., p. 14). However, even then, women were called upon to participate in "building the land" to serve the growing needs of the Jewish state (Kark, 2004, p. 139). 


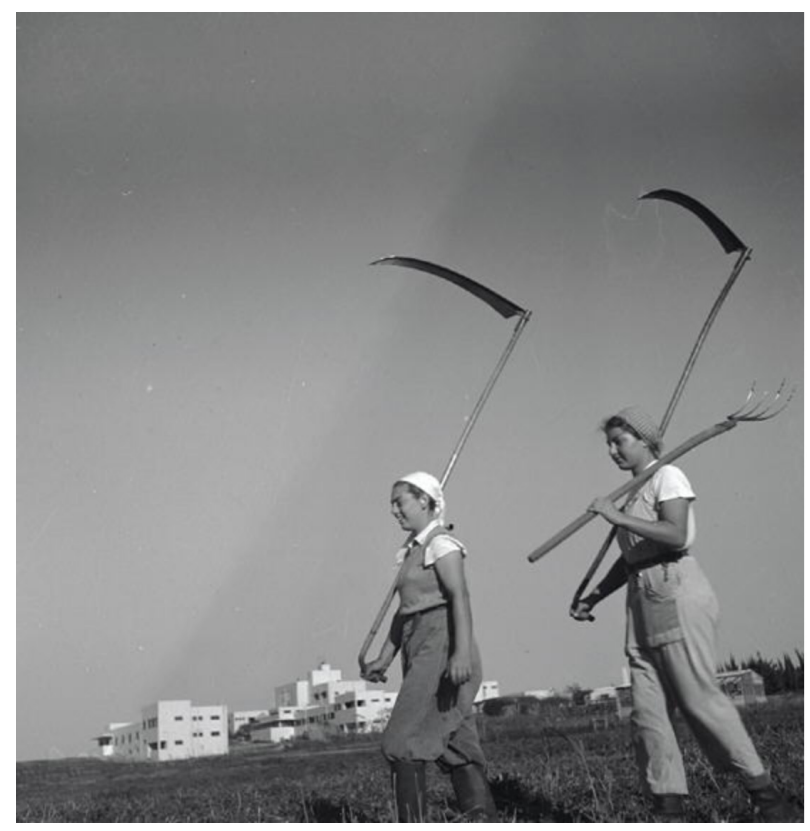

Figure 6.5: “The Po'alot (female workers) in the agricultural settlement Ayanot," Jan 2, 1940. Source: Schwartz Tel Aviv. From the The Jewish National Fund (JNF) Photographic Archive.

Yet if Zionism's inclusion of women in the public sphere could be considered feminist, it was only conditionally so. Zionism's early focus was wedded to land, and women were portrayed as essential to Zionism; yet, women were still characterized as having an essentially feminine connection to the land: a connection that served to sustain the next generation of the Israeli state through the dual responsibilities of motherhood and subsistence farming. Like the feminized conceptions of "mother earth" or "mother nature," Zionism fetishied women for their unique and essentialized relationship to children in the same way that it fetishised their unique and essentialized relationship to the land. This view was mirrored by NGOs in the 1980s, teaches Melissa Leach, who "put forward the view that women were the primary users and managers of the environment at the local level” (Leach, 2007, p. 69; see also Dankelman \& Davidson, 1988; Rodda, 1991). At this time, NGOs around the world argued that women's work tied them intimately to the environment, especially in "reproductive and subsistencefocused activities" (Leach, 2007, p. 69).

At the same time as early Zionist factions were establishing themselves, Jewish organizations - most notably, the Jewish National Fund (JNF) - were founded to buy and develop land for Jewish settlement in Israel-Palestine. The JNF was founded in 1901 in what was then Ottoman Palestine, later British Mandate for Palestine. Together with its parent organization, today the JNF owns 93\% of the land of Israel, which cannot be leased to foreigners, non-Jews, or Palestinians (Israel Land Authority, 
2013). Notably, the JNF executed large campaigns of afforestation - distinct from the more common reforestation, which is planting trees where they once grew - instead introducing "trees to sites that never supported forests, or had no forest cover for a long period of ecological time" (Nyland, 1996). The JNF solicited donations from diasporic Jewry for its campaigns via its iconic blue donation boxes, to great effect and financial solvency. Today, many Jews donate money so that trees may be planted in Israel-Palestine in honor of loved ones or familial lifecycle events, and many even travel to Israel to plant the trees with their own hands (Jewish National Fund, n.d.).

In the early years, the JNF planted olive and fruit trees because of their romantic biblical associations (Stemple, 1998). But these trees required a lot of care. Therefore in the 1920s, the JNF switched to Aleppo pine trees (or Pinus halepensis), which became the main tree planted because it grew quickly and "suited the European image of a proper forest" (Shoham, 2017, p. 80). Others claim that the Pine was chosen for the acidic deposits its needles leave on the ground, which prevents undergrowth and deprives Palestinian shepherds of pasture (Weizman, 2007). The problematic focus on monoculture has created massive "Pine deserts" that now dominate Israeli forests, making them ecologically susceptible to devastating wildfires (Osem et al., 2011). Moreover, as of research released in 2014, more than two-thirds of the JNF forest sites are located on ruins of former Palestinian villages. In other words, the trees have been structurally planted to efface the visual traces of prior Palestinian inhabitation within the State of Israel (Ibid.; see also Weizman, 2007 and Berdugo, 2020).

What is striking about the violent colonialism of these JNF forests is the very innocence - and generally presumed goodness - of the simple act of planting a tree. This optimism is epitomized by the dedication of the book, Trees as Good Citizens, which is offered up in celebration of "every man, woman and child who plants a tree" (Pack, 1922). ${ }^{24}$ Likewise the US Secretary of Agriculture once proclaimed, "Every tree is beautiful, every grove is pleasant, and every forest is grand; the planting and care of trees is exhilarating and a pledge of faith in the future" (U.S. Department of Agriculture Forest Service, 1905, p. 10). Trees are held to be uncomplicatedly positive, and those who plant them are good. In this way they map cleanly on to the gendering of civilians in war: like a tree, a woman is presumed to be an innocent and vulnerable bystander - a victim just like the very scars left on a landscape itself. Certainly plants hold scars and other memories of damage. In the former village of Deir Yassin, twenty Palestinians were shot to death by Israeli paramilitary forces, with the fatal bullets piercing the prickly pear hedges behind them (see Figure 6.6). The cactus lived on, bearing the marks of this violence like a shadow, like a ghost.

24 This book even opens one of its chapters with the following poem: "What does he plant who plants a tree? / He plants, in sap and lead and wood, / In love of home and loyalty, / And far-cast thought of civic good / His blessing on the neighborhood" (p. 23). 


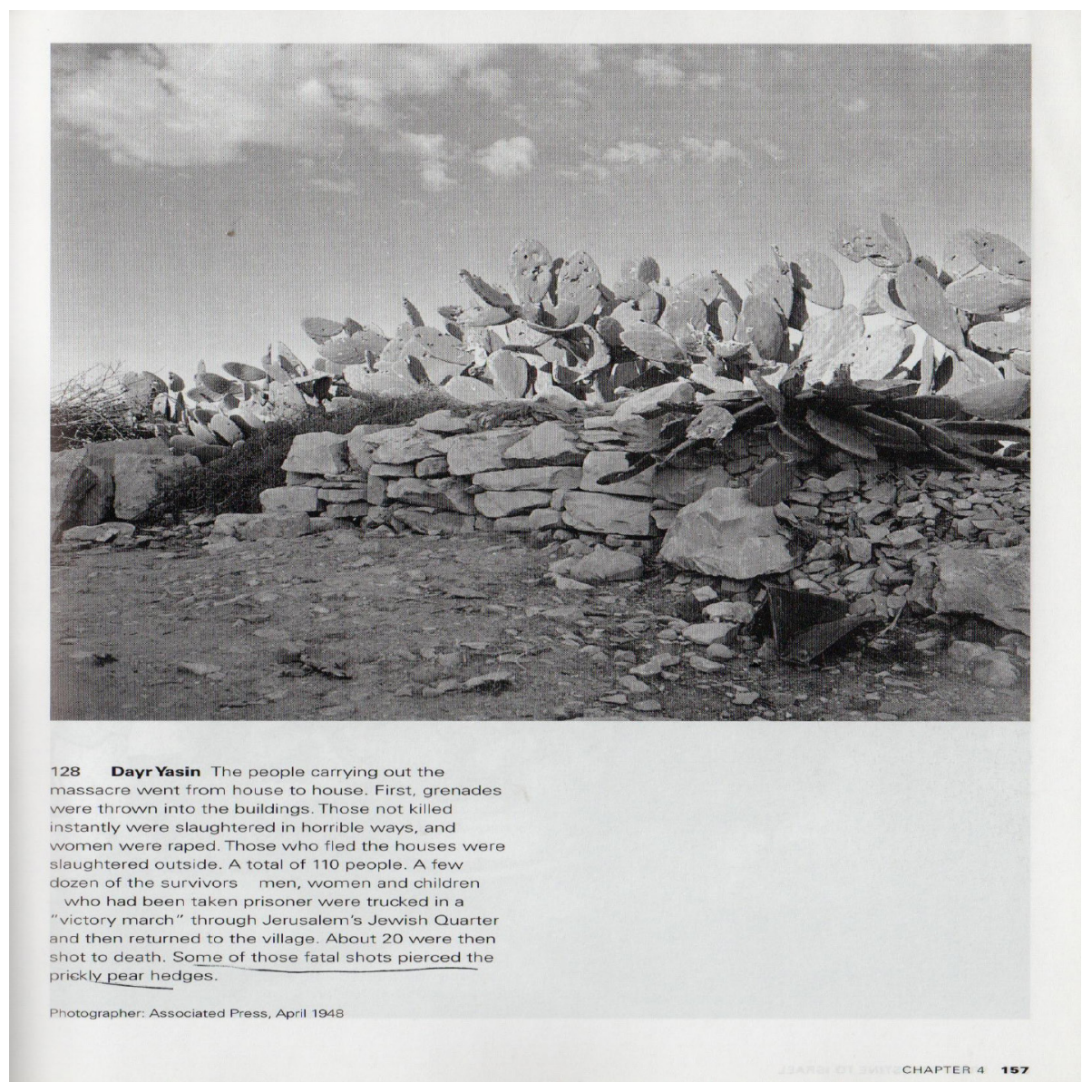

Figure 6.6: Deir Yassin (also transliterated as Dayr Yasin), Associated Press, April 1948.

\subsection{An Ecofeminist Critique of the Feminized Witness}

The feminized land, the feminized witness: ecofeminists would argue that both have been subjected to what Melissa Leach calls "a shared history of oppression by patriarchal institutions and dominant western culture” (2007, p. 70). From an over forty-year history of ecofeminist scholarship we are taught that women and nature share a mutual state of oppression from male-dominated society: women and nature are both seen as property, for instance; moreover, in the same way that men dominate women, humans dominate nature. In this way, the vast afforestation campaigns led by the JNF are part of an effort to dominate nature. Similarly, the subjugation of women to the role of passive "watchers" are part of systematic efforts to dominate or contain them under the patriarchy. Put differently, both women and nature have been 
subjected to what feminist philosopher Val Plumwood has called "the standpoint of mastery" of the self to the other, involving "seeing the other as radically separate and inferior, the background to the self as foreground." (Plumwood, 1993; Plumwood, 1996; Griffin, 2001, p. 284).

Against the backdrop of an ecofeminist critique, we can see that notions of women as possessing a natural or special relationship with the environment must be challenged alongside notions that women possess a special or uniquely innate ability to watch - especially over theland, itself - and to produce visual documentation of what they see. Instead, what might it look like to treat Palestinian women camerapersons as frontline defenders of human rights, who, like their male counterparts, record to oppose the occupation? In a 2016 panel that followed a screening of women-recoded B'Tselem videos at the Tel Aviv Cinematheque, one of the woman videographers was asked whether her 'womanness' uniquely affected her videos. Ginsburg described that this woman answered, without hesitation, "No, I just was there" (Ginsburg, in press, pp. 12-13). Indeed, what if Palestinian women videotape spectacular footage of the Israeli occupation because it is a horrific, monstrous spectacle of an occupation? Ecofeminists would argue that the notion of a uniquely feminized witness, who produces uniquely superior documentation, must be decommissioned as a mere social construction. An ecofeminist critique would further argue that such a conception of a woman B'tselem videographer is intricately and intersectionally linked to the subjugation of the land as a feminized and controllable commodity - a thing that can be afforested, sculpted, bought, owned, and fought over.

\subsection{Towards an Insurgent Way of Seeing}

In San Francisco's Prelinger Library, I came across a book titled Should Trees Have A Standing?, published by legal scholar Christopher Stone in 1974, the same year that French writer Françoise d'Eaubonne coined the term ecofeminism. Stone's book argues that trees and other natural objects should have their own legal rights, just as people and even corporations do. Trees could then claim damages when they were cut down; streams could demand reparations for pollution; and natural objects in general would have rights to "seek redress on their own behalf" through lawyers (Stone, 1974, p. 17). Perhaps this sounds absurd, but "each time there is a movement to confer rights onto some new 'entity' the proposal is bound to sound odd or laughable," wrote Stone (Ibid., p. 8). Certainly at one point it was laughable to bestow rights onto women, slaves, persons of color, and the incarcerated ${ }^{25}$; certainly, it is considered laughable under the current Israeli government to bestow rights to occupied Palestinians. Stone explains that this "is partly because until the rightless thing receives its rights, we

25 One could argue that those rights have never been properly bestowed. 
cannot see it as anything but a thing for those of us who are holding rights at the time" (Ibid.). Rights give 'things' agency to be more than things. Rights remove 'thingness', transforming things into bodies, entities, and states.

Palestinian women who film for B'Tselem are made into things twice over. First, they are 'thing-ed' by the Israeli regime by their status as Palestinians, who lack rights generally considered to be universally human under the UN's Universal Declaration of Human Rights (UN General Assembly, 1948). Secondly, these women are 'thing-ed' by the valorization of their position as feminized watchers, as feminized watchers and feminized producers of visual documentation. Contemporary Palestinian feminists remind us, though, that the primary cause of Palestinian women's subjugation and Palestinian society more broadly - is the Israeli occupation, not their status as women (Sayigh, 1981; Souad, 1994; Jad, 1995; Allabadi, 2008; Rought-Brooks et al., 2010). These feminists - together with ecofeminists - beg the question: what might it look like, visually, to treat the Israeli occupation itself as the preeminent subjugator of women B'Tselem volunteers? How might it appear to pay attention, with a sincere attention to vision and visuality, to Palestinian visual documentation of the Israeli occupation?

Following scholars like Judith Butler (2004, 2009) and Ariella Azoulay (2008, 2011b), I argue that what is needed is an insurgent way of seeing: a kind of vision that acts contrary to the dominant political regime by visibilizing the frames of images themselves - or to use Azoulay's terminology, that considers the photographic event as a whole, not merely the image that results from a photographic act. This kind of seeing is rebellious in its opposition to established norms and dominant scopic and political paradigms. Indeed, it is a shift in comprehension of what injustices these images seek to remedy, from what legal scholar Nancy Fraser defines as ordinarypolitical misrepresentation to the much more severe metapolitical injustice (2008). Injustices of ordinary-political misrepresentation are injustices in which a civil society and its government denies people who are generally agreed to be members of that society the opportunity to participate in decision making, as peers or equals. As Fraser describes, these political injustices occur within political societies "whose boundaries and membership are widely assumed to be settled” (Ibid., p. 407). For instance, ordinary-political misrepresentational injustice occurs when a citizen is denied a fair trial under law, for instance. Such injustices occur "when a polity's rules for decision making deny some who are counted in principle as members the chance to participate fully...” (Ibid.). The citizenship or membership of such a person into a political community has not been called into question, as it is generally agreed. Instead, the injustice occurs from the mistreatment of that citizen by the polity.

The second and more severe level on injustice is one in which civil society and its government wrongly draw the boundaries of citizenship. This kind of injustice, called metapolitical injustice, entails the denial of civil membership to a population, or the denial of its opportunity to participate in what Fraser calls "authorized contests over 
justice" such as elections (Ibid., p. 408). ${ }^{26}$ Metapolitical injustice arises "as a result of the division of political space into bounded polities" or when "a polity's boundaries are drawn in such a way as to wrongly deny some people the chance to participate at all in its authorized contests over justice” (Ibid.). In such cases, a person is not simply denied the right to ordinary-political representation, but denied the very right of constituting a body that is entitled to political representation at all. Here I think of the American civil rights movement, and its work against the mischaracterization of African-Americans as non-Americans who were not entitled to the right to vote. This kind of justice is a second-order injustice. It is meta political, of a higher order than the realm of the political, itself. This injustice is perpetrated by an act of misframing persons outside of the edges of the political, as if pushing them outside the boundaries of a frame, a photograph.

Just as ecofeminists teach us that what is needed to protect ecology is not a feminized conception of nature, I have shown that what is needed is not a celebrated feminized witness. Instead, what is needed is an insurgent, disobedient way of seeing that conceptualizes events captured as metapolitically unjust. Put differently, what is demanded by this way of seeing is not a celebration of the female witness, the female gaze, or the feminized connection to nature; instead, this way of seeing consider the frame of the image to be the problem, itself. This is, ultimately, a way of seeing that elevates citizen videography in zones of conflict to engage in radically new possibilities of resistance.

\section{Acknowledgements}

I thank the staff and volunteers at B'Tselem for their generosity and accomodation, which has made this research possible. Thank you to my Arabic language translator, Yuval Orr; and to the Dorot Foundation whose funding has enabled portions of this research.

\section{References}

a-Deb’i, S. (2019, February 5). Personal Interview (L. Berdugo, Interviewer; Y. Orr, Trans.) [Personal communication].

al-Ja’bri, A. (2019, February 4). Personal Interview (L. Berdugo, Interviewer; Y. Orr, Trans.) [Personal communication].

al-Ja’bri, M. (2019, February 4). Personal Interview (L. Berdugo, Interviewer; Y. Orr, Trans.) [Personal communication].

26 A citizen can be denied of the right to vote, or denied the right to elect equal representation by, say, district gerrymandering. 
Allabadi, F. (2008). Secular and Islamist Women in Palestinian Society. European Journal of Women's Studies, 15(3), 181-201.

Andrews, L. B. (2012). I know who you are and I saw what you did: Social networks and the death of privacy. Simon and Schuster.

Azoulay, A. (2008). The civil contract of photography (R. Mazali \& R. Danieli, Trans.). Zone Books.

Azoulay, A. (2011a). From Palestine to Israel: A photographic record of destruction and state formation, 1947-50. Pluto Press.

Azoulay, A. (2011b). Photography: The Ontological Question. Mafte'akh, 2e, 65-80. http:// monoskop.org/images/8/82/Azoulay_Ariella_2011_Photography_The_ontological_question. pdf

Azoulay, A. \& Ophir, A. (2005). The Monster's Tail. In M. Sorkin (Ed.), Against the wall: Israel's barrier to peace. The New Press.

Baxter, D. (2007). Honor Thy Sister: Selfhood, Gender, and Agency in Palestinian Culture. Anthropological Quarterly, 80(3), 737-775. https://doi.org/10.1353/anq.2007.0037

Berdugo, L. (2017, August 22). Spectral Power. Real Life Magazine. http://reallifemag.com/ spectral-power/

Berdugo, L. (2020). A Situation: A Tree in Palestine. Places Journal. https://placesjournal.org/ article/a-situation-a-tree-in-palestine/

Berdugo, L. (2021). The Weaponized Camera in the Middle East: Videography, Aesthetics and Politics in the Israel and Palestine. Bloomsbury.

BlueServo. (n.d.). Retrieved May, 24, 2019, from http://www.blueservo.com/

B'Tselem. (2005a). B'Tselem Staff - The Wayback Machine. Retrieved January, 5, 2020 from http:// web.archive.org/web/20050810025108/http://www.btselem.org/english/About_BTselem/ Staff_Members.asp

B'Tselem. (2005b). About B'Tselem - The Wayback Machine. Retrieved January, 5, 2020 from http:// web.archive.org/web/20050308111422/http://www.btselem.org/English/About_BTselem/ Index.asp

B'Tselem. (2005c). B'Tselem Video - The Wayback Machine. Retrieved January, 5, 2020 from http:// web.archive.org/web/20051210222750/http://www.btselem.org/English/Video/Index.asp

B'Tselem. (2006). Documentary: Separation Barrier's Consequences for Farmers. [Video] Retrieved January, 5, 2020 from www.youtube.com/watch?v=k4bC1hKucQA

B'Tselem. (2007). “Sharmuta Video" - Settler Harassment of Palestinians in Hebron. [Video] Retrieved January, 5, 2020 from www.youtube.com/watch?v=KUXSFsJV084

B'Tselem. (2008a). Shooting Back - The Wayback Machine. Retrieved January, 5, 2020 from http:// web.archive.org/web/20080414161342/http://www.btselem.org/english/Video/Shooting_ Back_Background.asp

B'Tselem. (2008b). B'Tselem's Staff - The Wayback Machine. Retrieved January, 5, 2020 from http:// web.archive.org/web/20080524075508/http://www.btselem.org/english/About_BTselem/ Staff_Members.asp

B'Tselem. (2009). B'Tselem's Video Camera Distribution Project Wins British One World Media Award. Retrieved January, 5, 2020 from www.btselem.org/press_releases/20090623

B'Tselem. (2014a, March). Camera savvy: Video-training seminar for women volunteers, village of Burin, 8 Jan. 2014. Eyes Wide Open | Photo Blog. www.btselem.org/photoblog/2014_ international_womens_day

B'Tselem. (2014b, March 5). Khadrah tells what it's like to film settler attacks. Int'l Women's Day 2014. [Video] www.youtube.com/watch?v=XKQ9ihQtdb8

B'Tselem. (2014c, March 6). Filming to protect our families. International Women's Day 2014. [Video] www.youtube.com/watch?v=nY6aVYjWQ6s\&feature=youtu.be 
B'Tselem. (2017). Israeli soldiers drag 8-year-old from home to home looking for stone-throwers, Hebron, March 2017. Retrieved January, 5, 2020 from https://www.youtube.com/ watch?v=erZKXJOkV9s

B’Tselem. (2018). 2017 Annual Report. www.btselem.org/sites/default/files2/2017_activity_report. pdf

Burnett, J. (2009, February 23). A New Way To Patrol The Texas Border: Virtually. NPR.Org. https:// www.npr.org/templates/story/story.php?storyld=101050132

Butler, J. (2004). Precarious life: The powers of mourning and violence (Gleeson Stacks HV6432 .B88 2004). Verso.

Butler, J. (2009). Frames of war: When is life grievable? (Gleeson Stacks HM1116 .B88 2009). Verso.

Caplan, N. (2011). The Israel-Palestine Conflict Contested Histories. John Wiley \& Sons.

Carpenter, R. C. (2006). Innocent women and children: Gender, norms and the protection of civilians. Ashgate.

Carter Hallward, M. (2008). Negotiating boundaries, narrating checkpoints: The case of Machsom Watch. Critique: Critical Middle Eastern Studies, 17(1), 21-40.

d'Eaubonne, F. (1974). Le féminisme ou la mort. Pierre Horay.

Dajani, S. (1994). Between National and Social Liberation: The Palestinian women's movement in the Israeli occupied West Bank and Gaza Strip. In T. Mayer (Ed.), Women and the Israeli occupation: The politics of change. Routledge.

Dankelman, I. \& Davidson, J. (1988). Women and environment in the Third World: Alliance for the future (Reprinted). Earthscan.

Feldman, A. (1997). Violence and Vision: The Prosthetics and Aesthetics of Terror. Public Culture, 10(1), 24-60. https://doi.org/10.1215/08992363-10-1-24

Finn, J. (2009). Capturing the criminal image: From mug shot to surveillance society. University of Minnesota Press.

Foucault, M. (1994). The Birth of the Clinic: An Archaeology of Medical Perception. Vintage.

Fraser, N. (2008). Abnormal justice. Critical Inquiry, 34(3), 393-422. https://doi. org $/ 10.1086 / 589478$

Gelvin, J. L. (2014). The Israel-Palestine conflict: One hundred years of war (Third Edition). Cambridge University Press.

Gerner, D. (1994). One Land, Two Peoples: The Conflict over Palestine. Routledge. https://doi. org/10.4324/9780429494918

Ginsburg, R. (2011). Taking Pictures over Soldiers' Shoulders: Reporting on Human Rights Abuse from the Israeli Occupied Territories. Journal of Human Rights, 10(1), 17-33.

Ginsburg, R. (In Press). Armed with a Camera: Gendering Visual Documentation in the Case of Israel/ Palestine. Signs: Journal of Women in Culture and Society.

Ginsburg, R. (2016). Gendered visual activism: Documenting human rights abuse from the private sphere. Current Sociology, 66(1), 38-55. https://doi.org/10.1177/0011392116651115

Griffin, N. (2001). Val Plumwood, 1939-. In J. Palmer (Ed.), Fifty Key Thinkers on the Environment. Routledge.

Gross, J. A. (2015, October 22). The Gaza border fence won't protect you, but the IDF will. The Times of Israel. https://www.timesofisrael.com/the-gaza-border-fence-wont-protect-you-but-theidf-will/

Halperin, I. (2007). Between the lines: The story of Machsom Watch. Journal of Humanistic Psychology, 47(3), 333-339.

Harel, A. (2003, November 5). Soldiers Can Shoot Gazans Spying on Netzarim. Haaretz. https://www. haaretz.com/1.4752144

Harel, A. (2017, June 22). Israel Speeds Up Camera Placements in West Bank in Effort to Deter Terrorism. Haaretz. www.haaretz.com/israel-news/.premium-idf-speeds-up-cameraplacements-in-w-bank-in-effort-to-deter-terrorism-1.5485764 
Hesford, W. (2011). Spectacular rhetorics: Human rights visions, recognitions, feminisms. Duke University Press.

IDF Central Command. (2009). Subject: Your request concerning photography and videography by B'Tselem staff and volunteers. https://www.btselem.org/download/20091130_central_ command_response_to_letter_on_soldiers_obstructing_photographers_heb.pdf

Is Tazpitanit an intersting army role? Or should I fight for something else? (n.d.). 9CHAT: Get Cookie. Retrieved May, 24, 2019 from http://getcookie.com/p/aWoNkz9Nb

Jad, I. (1995). Claiming Feminism, Claiming Nationalism: Women's Activism in the Occupied Territories. In A. Basu (Ed.), The Challenge of local feminisms: Women's movements in global perspective (Gleeson Stacks HQ1101 .C46 1995). Westview Press.

Jewish National Fund. (n.d.). Plant a Tree. Retrieved May 30, 2019, from http://usa.jnf.org/jnf-treeplanting-center/

Kaplan, E. (2001). Decadent pioneers: Land, space and gender in Zionist revisionist thought. Journal of Israeli History, 20(1), 1-23. https://doi.org/10.1080/13531040108576147

Kark, R. (2004). "Not a Suffragist”? Rachel Yanait Ben-Zvi on Women and Gender. Nashim: A Journal of Jewish Women's Studies \& Gender Issues, 7, 128-150. http://search.ebscohost. com/login.aspx?direct=true\&AuthType $=$ sso\&db=edsjsr\&AN=edsjsr. $40326575 \&$ site $=$ edslive \&scope $=$ site $\&$ custid $=$ s3818721

Kutz-Flamenbaum, R. V. (2012). Mobilizing gender to promote peace: The case of Machsom Watch. Qualitative Sociology, 35(3), 293-310.

Leach, M. (2007). Earth Mother Myths and Other Ecofeminist Fables: How a Strategic Notion Rose and Fell. Development and Change, 38(1), 67-85.

Lebow, A. (2012). Shooting with Intent. In J. Ten Brink \& J. Oppenheimer (Eds.), Killer images: Documentary film, memory and the performance of violence (Gleeson Stacks PN1995.9.D6 K54 2012; pp. 41-61). Wallflower Press.

Mackey, R. (2009, March 26). Thousands Sign Up for Virtual Border Patrol. The New York Times. https://thelede.blogs.nytimes.com/2009/03/26/thousands-sign-up-for-virtual-border-patrol/

Maimon, V. \& Grinbaum, S. (Eds.). (2016). Activestills: Photography as protest in Palestine and Israel. Pluto Press.

Mirzoeff, N. (2011). The Right to Look. Critical Inquiry, 37(3), 473-496. https://doi. org $/ 10.1086 / 659354$

Moll, J. (2014, July 8). Surveillance through Social Networks along with US-Mexico Border. Electronic Visualisation and the Arts 2014. https://doi.org/10.14236/ewic/eva2014.19

Plumwood, V. (1993). Feminism and the mastery of nature. Routledge.

Plumwood, V. (1996). Androcentrism and Anthrocentrism: Parallels and Politics. Ethics and the Environment, 1(2), 119-152. https://www.jstor.org/stable/27766018

Rodda, A. (Ed.). (1991). Women and the environment. Zed Books.

Rosenberg-Friedman, L. (2018). Religious-Zionism and Gender: 70 Years of Redefining the Identity of Women in the Military, Religious, and Public Spheres. Israel Studies, 23(3), 152-163. http:// search.ebscohost.com/login.aspx?direct=true\&AuthType=sso\&db=edspmu\&AN=edspmu. S1527201X18300188\&site $=$ eds-live \&scope $=$ site $\&$ custid $=$ s3818721

Rought-Brooks, H., Duaibis, S., \& Hussein, S. (2010). Palestinian Women: Caught in the Cross Fire Between Occupation and Patriarchy. Feminist Formations, 22(3), 124-145. https://www.jstor. org/stable/40980987

Rubinstein, E. (2015, November 25). On Zionism and Gender-The Young Women's Farm. The Times of Israel. http://blogs.timesofisrael.com/on-zionism-and-gender-the-young-womens-farm/

Sayigh, R. (1981). Encounters with Palestinian Women under Occupation. Journal of Palestine Studies, 10(4), 3-26. https://doi.org/10.2307/2536386 
Silkoff, S. (2018, September 13). I'm in the IDF. So how did I get here? The Jewish Chronicle. https:// www.thejc.com/comment/blogs/i-m-in-the-idf-so-how-did-i-get-here-lone-soldier-blog-shirasilkoff-1.469746

Sontag, S. (2002, December 2). Looking at War. The New Yorker. https://www.newyorker.com/ magazine/2002/12/09/looking-at-war

Suttler, J. (2009, March 12). Guarding the U.S.-Mexico border, live from suburban New York. CNN. http://edition.cnn.com/2009/TECH/03/12/border.security.cameras.immigration/index.html

Tarabieh, E. (2019, February 10). Personal Interview (L. Berdugo, Interviewer) [Personal communication].

Tewksbury, D. (2012). Crowdsourcing Homeland Security: The Texas Virtual BorderWatch and Participatory Citizenship. Surveillance \& Society, 10(3/4), 249-262.

Texas Border Watchers BlueServo. (n.d.). Facebook. https://www.facebook.com/ groups/2217025407/?ref=group_header

UN General Assembly. (1948). Universal Declaration of Human Rights (217 A (III)). https://www. refworld.org/docid/3ae6b3712c.html

U.S. Department of Agriculture Forest Service. (1905). Forest Preservation and Natural Prosperity (Circular No. 35).

Virilio, P. (2009). War and cinema: The logistics of perception (P. Camiller, Trans.). Verso Books.

Warriner, I. \& Tessler, M.A. (1997). Gender, Feminism, and Attitudes Toward International Conflict: Exploring Relationships with Survey Data from the Middle East. World Politics, 49(2), 250-281. https://doi.org/10.1353/wp.1997.0005

Yom Hame'ah. (2015, July 25). Mitnadevet. http://mitnadevet.wordpress.com/tag/idf/page/2/

Zaban, W. (2019, February 5). Personal Interview (L. Berdugo, Interviewer; Y. Orr, Trans.) [Personal communication].

Zraqo, S. (2019, February 4). Personal Interview (L. Berdugo, Interviewer; Y. Orr, Trans.) [Personal communication]. 